\title{
Inflation Risk?
}

Inflation is on the rise again in the industrialised world. This has led to fears of a sustained surge in inflation. This article argues that while such fears may make sense in the US, they do not in the eurozone, where the monetary-fiscal policy mix has been much less expansionary than in the US. The fear expressed by some that the monetary overhang from the large injections of liquidity through quantitative easing might lead to inflation in the eurozone does not stand up to scrutiny either. The conclusion offers some observations on the monetary operating procedures in the ECB. It argues that in the future, when interest rates rise again, the ECB risks transferring all (and even more) of its profits to the banking system. This article proposes a way to avoid this unacceptable outcome.

Inflation is on the rise again in the industrialised world. In the US, the inflation rate reached $5.4 \%$ in June 2021 ; in the eurozone inflation was estimated to be $1.9 \%$ in the same month. Should we worry about this surge in inflation? In order to answer this question, one must answer a preliminary one: What are the causes of this increase in inflation?

The short answer is that it has everything to do with the economic recovery from the pandemic that hit the world in 2020. This recovery has been made possible by two things: the release of excess savings accumulated during 2020 and strong expansionary fiscal and monetary policies, especially in the US, where the mix of fiscal and monetary policy has been extraordinarily expansionary. While US GDP growth declined by $5.8 \%$ in 2020 , the budget deficit increased by $10.7 \%$ of GDP. Thus, for every $1 \%$ decline in GDP, the US fiscal authorities allowed the budget deficit to increase by almost $2 \%$ of GDP. This compares with a decline in eurozone GDP of $7.5 \%$ and an increase in the budget deficit of $6.4 \%$. In other words, for every $1 \%$ decline in GDP in the eurozone, fiscal authorities allowed the budget deficit to increase by less than $1 \%$ of

(C) The Author(s) 2021. Open Access: This article is distributed under the terms of the Creative Commons Attribution 4.0 International License (https://creativecommons.org/licenses/by/4.0/).

Open Access funding provided by ZBW - Leibniz Information Centre for Economics.

Paul de Grauwe, London School of Economics, UK.
GDP. Thus, it appears that the fiscal expansion was about twice as strong in the US compared to the eurozone.

A similar story emerges from monetary policies. Both the US Fed and the ECB intensified their asset purchases since the start of the pandemic, thereby flooding the markets with liquidity. But again, the amount of asset purchases was significantly higher in the US than in the eurozone. Since January 2020, the US Fed bought approximately $\$ 2.6$ trillion in government securities, about twice the amount bought by the ECB, $€ 1.3$ trillion, thereby increasing the amount of liquidity in the US significantly relative to the eurozone.

It appears that since the start of the pandemic, monetary and fiscal policies have been expansionary in both the US and the eurozone, but that the intensity of this expansion has been much higher in the former. This has led some to argue (e.g. Summers, 2021; Blanchard, 2021) that the US fiscal-monetary policy mix is excessive and exceeds the capacity of the economy to absorb it without major price increases. This probably explains why the surge in inflation is much higher in the US than in the eurozone. I conclude from this that while the risk of inflation is real in the US, it is much less so in the eurozone, where monetary and fiscal expansion does not appear to be hitting capacity constraints in the economy.

Diehard monetarists will probably object to this conclusion. Quantitative easing (QE) performed by the ECB since 2015 has created a monetary overhang. Does this overhang not create a risk for future inflation? Did Milton Friedman not teach us that inflation is always and everywhere a monetary phenomenon ? The fact is that the QE programme of the ECB has led to a surge in the money 
Figure 1

Inflation and M3 growth rate in the eurozone

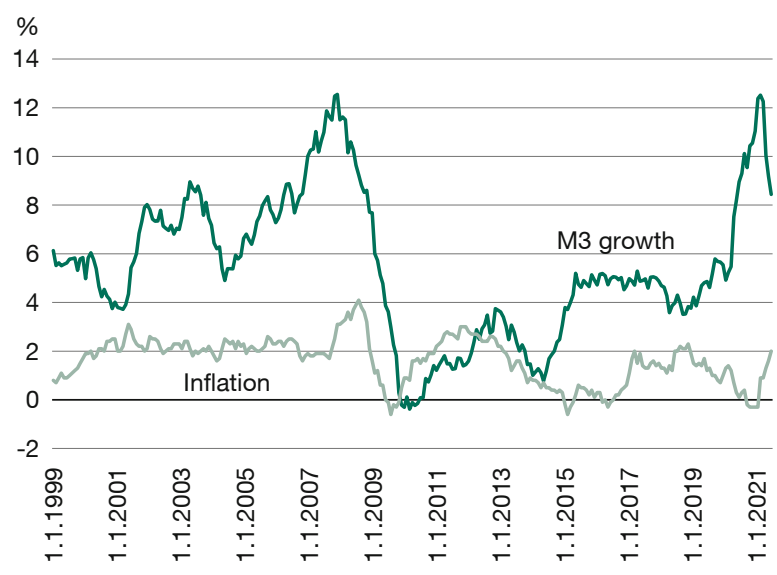

Source: European Central Bank.

stock in the eurozone. This in the end will lead to a surge in inflation, according to this monetarist analysis.

Let us look at the numbers. This is done in Figures 1 and 2. Figure 1 shows the evolution in time of inflation and the growth rate of $\mathrm{M} 3$ in the eurozone. We observe first that the relation between these two variables is weak. This is also confirmed by Figure 2, which shows the same numbers in a scatter diagram, with M3 growth on the horizontal axis and inflation on the vertical one. A simple regression line, which is almost horizontal, shows that there is no significant relation at all between money growth and inflation. Of course, one might argue that this figure only measures the short-term relation between money growth and inflation, while the monetarist theory tells us that this relation only holds in the long run. De Grauwe and Polan (2005) looked at the long-run relationship between money growth and inflation (over a 30-year period) for about 100 countries and concluded that, except for countries experiencing hyperinflation, there is no significant longrun relation between money growth and inflation.

Coming back to Figure 1, we observe two waves in the expansion of the money stock in the eurozone. There is the pre-financial crisis wave of monetary expansion that reached yearly growth rates of more than $10 \%$ from 2006 to 2008 , and there is the post-2015 wave that led to increases in the money stock exceeding $10 \%$ in 2020. Both waves of monetary expansion that were sustained over five years or more do not seem to have affected inflation much (confirming our previous observations). The pre-financial crisis wave, however, teaches us that the risk was elsewhere, i.e. in the financial markets. Underlying the strong growth in $\mathrm{M} 3$ there was the surge in
Figure 2

Inflation and M3 growth in the eurozone, 1999-2021

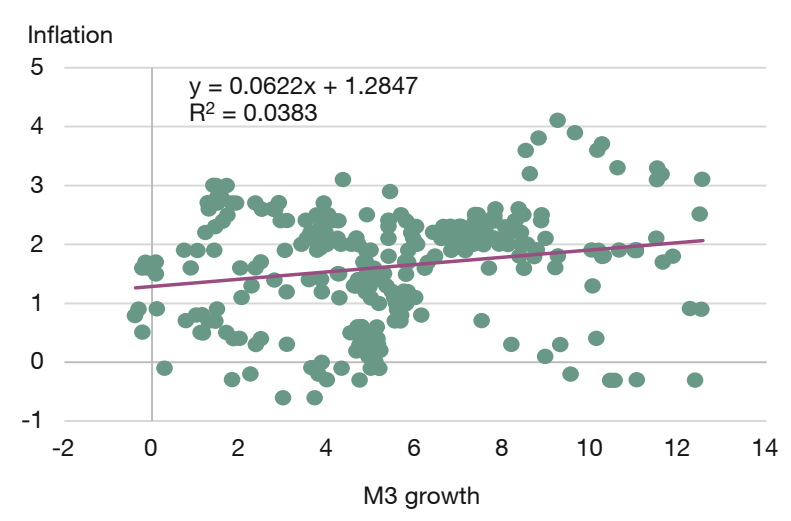

Source: European Central Bank.

bank credit that fuelled real estate and other bubbles. Ultimately, this led to the banking crisis of 2007-08. Will history repeat itself?

From the preceding, I conclude that the risk of a significant surge in inflation in the eurozone appears to be limited. This contrasts with the US, where the risk appears to be more serious. However, the large expansion in liquidity both in the US and in the eurozone creates potential risks in financial markets. These might affect the future conduct of monetary policies.

At some point when inflation returns to its normal level, central banks will have to raise interest rates. These interest rate increases create two potential problems that may act as obstacles for these interest rate increases.

The first one relates to the problem just identified. An interest rate increase may destabilise financial markets, in particular the bond markets. Interest rate increases will lower bond prices and affect the balance sheets of many financial institutions (banks, pension funds, insurance companies). Can such an increase in the interest rate be done in an orderly way that minimises the risks of a financial crisis? There is no easy answer to this question. The uncertainty about this may induce central banks to wait too long to raise interest rates.

The second obstacle derives from the way central banks conduct monetary policies. For about 20 years, major central banks (including the Fed and the ECB) have switched to an operating system in which they remunerate banks' reserves held at the central bank. This means that when central banks have to raise the interest rate, it 
will affect their profit and loss account. This effect will be particularly pronounced for the ECB. At the end of 2020, bank reserves held at the ECB amounted to a massive $€ 3.5$ trillion (mostly the result of the large bond purchase programmes of the ECB). A $1 \%$ increase in the interest rate means that the ECB will have to pay out $€ 35$ billion to the banks holding these reserves. Going back to normal implies that the short-term interest rate would probably increase to $2 \%$, leading to interest payments to banks of $€ 70$ billion. This represents about three times the annual profits recorded by the ECB, €10-€20 billion during 1999-2017 (Chiacchio et al., 2018), and thus would lead to massive losses of that institution. This could make the ECB reluctant to raise interest rates when this becomes necessary.

There is no easy way out of this problem. One possibility would be for the ECB to massively sell government bonds again, thereby reducing bank reserves. This would not only raise long-term bond rates significantly but, more importantly, it would imply that the government debt relief that is implicit when the ECB holds government bonds on its balance sheet would be reversed. This would put new pressure on member states' budgets, especially those with large outstanding debt levels. It could also trigger a new sovereign debt crisis.

My favourite solution to this conundrum would be for the central bank to return to the old operating procedure of not remunerating bank reserves. There is no good economic argument why banks should be remunerated for holding liquid assets. Holders of banknotes are not remunerated either. The current operating procedure that pays bankers for holding liquid reserves will in normal times ensure that all (if not more) of the seigniorage gains that should go to the Treasury are actually transferred to financial institutions. This is an unacceptable outcome. The old operating procedure together with the use of minimum reserve requirements can be made to work again (as it did in the past) and provide for a better tool to conduct monetary policies in normal times.

\section{References}

Blanchard, O. (2021), In defence of concerns over the $\$ 1.9$ trillion relief plan, Real Time Economic Issues Watch Blog, Peterson Institute for International Economics.

Chiacchio, F., G. Claeys and F. Papadia (2018), Should we care about central banks profits, Policy Contribution, 13, Bruegel.

De Grauwe, P. and M. Polan (2005), Is Inflation Always and Everywhere a Monetary Phenomenon, Scandinavian Journal of Economics, 107(2), 239-259.

ECB (2020), Consolidated balance sheet of the Eurosystem, December 31.

Summers, L. (2021), The inflation risk is real, http://larrysummers. com/2021/05/24/the-inflation-risk-is-real/ (29 July 2021). 